\title{
Pembuatan Pembangkit Listrik Tenaga Hybrid Solar Cell dan Pico Hydro di Dusun Wukirsari
}

\author{
Slamet Hani' ${ }^{1)}$, Gatot Santoso'), Muhamad Wahyu Firmansyah ${ }^{3)}$ \\ Program Studi Teknik Elektro, Fakultas Teknologi Industri \\ Institut Sains \& Teknologi Akprind Yogyakarta
}

J1. Kalisahak No.28 Balapan Daerah Istimewa Yogyakarta 55222 Indonesia

Email: shan.akprind@gmail.com ${ }^{1)}$,gatsan@akprind.ac.id ${ }^{2)}$,Wahyu959678@gmail.com ${ }^{3)}$

\begin{abstract}
ABSTRAK
Sumber aliran air pada sungai atau saluran irigasi mempunyai debit aliran air relatif kecil yang berpotensi dimanfaatkan sebagai pembangkit listrik tenaga pico hydro. Salah satu komponen utama pembangkit listrik tenaga pyco hydro adalah kincir air, pembangkit listrik tenaga hybrid pyco hydro adalah suatu gabungan antara pembangkit listrik tenaga air dan tenaga surya. Dengan memanfaatkan tenaga dari aliran arus air pada sungai kecil atau selokan di dusun Wukirsari, maka merancang sebuah kincir air yang akan mengubah energi gerak menjadi energi listrik. Perancang sistem solar panel menggunakan solar cell $50 \mathrm{wp}$, inverter $300 \mathrm{~W}$, solar charger controller 10 A, dan baterai 12 Volt, 32 Ah. Hasil pengujian tanpa beban pada kinerja single kincir dan kinerja double kincir di ketinggian air $37 \mathrm{~cm}$ mendapatkan nilat ratarata daya sebesar 3,2 $\mathrm{W}$ dan 2,11 W. Tegangan yang dihasilkan 6,72 V, arusnya 0,46 A untuk single kincir, typo untuk double kincir tegangannya 5,36 V dan arusnya 0,38 A. Dari hasil percobaan antara single kincir dan double kincir lebih baik menggunakan single kincir. Pada rangkaian solar panel tanpa beban dari hasil pengujian daya yang dihasilkan, pada jam 11.00 wib mendapatkan nilai daya yang paling tinggi yaitu 33,25 W. Listrik yang dihasilkan tenaga hybrid pico hydro dimanfaatkan masyarakat Dusun Wukirsari sebagai penerangan jalan.
\end{abstract}

Kata kunci : kincir air, tenaga hibrid, solar panel

\begin{abstract}
The source of water flow in rivers or irrigation canals has a relatively small flow rate of water, which can be used as a pico hydropower plant. One of the main components of a pico hydropower plant is a water wheel, a hybrid pico hydropowerplant is a combination of hydroelectric power and solar power. By utilizing the power of the water flow in a small river or ditch in Wukirsari hamlet, we designed a waterwheel that will convert the energy of motion into electrical energy. The solar panel system designer uses a 50 wp solar cell, a $300 \mathrm{~W}$ inverter, a 10 Ampere solar charger controller, and a 12 Volt, 32 Ah battery. The no-load test results on the performance of the single pinwheels and the performance of the double pinwheels at a water level of $37 \mathrm{~cm}$ get an average power of $3.2 \mathrm{~W}$ and $2.11 \mathrm{~W}$. The resulting voltage is $6.72 \mathrm{~V}$, the current is 0.46 A for a single mill, while for the double pinwheel the voltage is 5,26, and the current is $0.38 \mathrm{~A}$. From the experimental results, it is better if the single pinwheel and the double pinwheel are used. In a series of noload solar panels fromPower test results, at $11.00 \mathrm{GMT}+7$ the highest power value was $33.25 \mathrm{~W}$. The electricity generated by the pico hydro hybrid was used by the people of Wukirsari Hamlet as street lighting.
\end{abstract}

Key words: water wheel, hybrid power, solar panels

\section{Pendahuluan}

Desa Wukirsari terletak di Kecamatan Imogiri Kabupaten Bantul, Propinsi DIY yang memiliki saluran irigasi sejauh \pm 100 meter yang berhulu di Sungai Opak dan belum dimanfaatkan oleh warga, maka dengan memanfaatkan saluran irigasi ini peneliti merancang alat pembangkit listrik tenaga pico hydro. 
Kincir air adalah komponen utama dari piko hydro. Pengujian kincir air sudu segitiga dilakukan dengan menguji model kincir air lengkap dengan bak uji model sistem PLTPH (pembangkit listrik tenaga pico hydro) (Mesin et al., 2017).

Untuk mengetahui sudut sudu kincir air sudu segitiga yang optimal, maka perlu melakukan pengujian sudut kincir dengan sudut $70^{\circ}, 80^{\circ}, 90^{\circ}, 100^{\circ}$ dan $110^{\circ}$. Dari pengujian yang dilakukan diperoleh efisiensi kincir tertinggi mencapai $27,1 \%$ pada sudu dengan sudut 100 derajat (Budiartawan et al., 2017).

Debit air sangat berpengaruh terhadap putaran generator pada pembangkit listrik tenaga picohydro, jika debit air tinggi maka pengisian akan lebih cepat. Sebaliknya saat debit air menurun pengisian akan lama. Debit air rata-rata 0,061-0,065lt dapat memutar generator $371 \mathrm{rpm}$ menghasilkan tegangan rata-rata 17,5 V. Pada tegangan yang dihasilkan dari inverter sebesar $220 \mathrm{~V}$ dapat mensuplai sejumlah lampu 5 berukuran $15 \mathrm{~W}$. Hasil pengujian generator menghasilkan tegangan $12 \mathrm{~V}$ AC dengan arus 2 A dikonversi ke inverter tegangan DC ke AC menjadi $220 \mathrm{~V}$ dengan daya 100 Watt (Alipan \& Yuniarti, 2018).

Dari hasil simulasi dan perhitungan pembangkit listrik tenaga pico hydro mampu menghasilkan tegangan sebesar $45 \mathrm{~V}$, sedangkan daya yang didapatkan berdasarkan hasil perhitungan yaitu 66,4 W dan efisiensi keseluruhan sebesar 21,4\% (Barat, n.d.).

Kincir air dapat dipakai sebagai penggerak generator listrik di daerah pedesaan yang mempunyai sungai dengan aliran yang landai, namun aliran sungai selalu dinamis tergantung curah hujan pada daerah tersebut, sehingga desain kincir air harus bisa disesuaikan dengan level ketinggian air dan kecepatan aliran. Diameter kincir, lebar kincir, diameter poros, pemilihan generator, rasio transmisi v-belt dan ECVT typy tempat dudukan mengapung merupakan bagian yang akan dirancang untuk mendukung dalam pembuatan alat pico hydro (Wibawa et al., n.d.).

Energi yang dihasilkan dari kincir air merupakan energi terbarukan yang dapat diukur dengan menggunakan digital torque tester yang dihubungkan dengan sumbu comodel kincir. Besar kecilnya kecepatan putaran akan sangat dipengaruhi oleh beban yang diberikan, karena pada kecepatan putaran yang tinggi belum tentu mempunyai energi yang besar (Junaidi et al., 2014).

Berdasarkan penelitian sebelumnya maka pada pengabdian ini akan dibuat suatu alat yang terdiri dari kincir air yang memiliki karakteristik kinerja masing-masing dan didukung dengan rangkaian solar panel agar menghasilkan energi listrik yang lebih maksimal. Kemudian alat tersebuat akan dimanfatkan untuk penerangan jalan di Desa Wukirsari.

\section{Metodologi}

Penelitian memerlukan beberapa alat dan bahan antara lain sebagai berikut:

\subsection{Alat yang dipakai yaitu:}

- Coreldraw, untuk membuat desain alat

- Alat ukur seperti tachometer, multimeter, tang amper untuk mengukur rpm, tegangan dan arus pada pengujian

- Berbagai ukuran kunci pas dan ring serta obeng, untuk membuka dan mengencangkan baut

- Solder, tenol, untuk menyambungkan komponen boost converter

- Mesin bor, bubut, las, gergaji besi, gerinda, untuk membuat kincir dan kerangka alat

\subsection{Bahan yang digunakan adalah sebagai berikut:}

- Solar panel $50 \mathrm{WP}$, untuk mengubah sinar matahari menjadi listrik

- Solar charge controller, untuk mengatur fungsi pengisian baterai

- Baterry $5 \mathrm{Ah}$, untuk menyimpan energi lisrik

- Inverter $300 \mathrm{~W}$, untuk merubah arus DC menjadi AC

- Generator DC 12-18 V, untuk merubah putaran dari kincir menjadi energi listrik

- Plat eser 1,2 mm, sebagai kerangka kincir air 
- Besi hollow, sebagai kerangka dudukan

- Besi poros (as), untuk meneruskan tenaga bersana dengan putaran kincir air

- Bantalan atau bearing, untuk mengurangi gesekan suatu putaran

- Pulley 3 \& 12 inc Sebagai penghubung mekanis dari putaran

- Belt atau Streng $59 \mathrm{~mm}$, untuk mentrasfer tenaga dari kincir air ke generator

- Baut dan mur, untuk menggabungkan antara kincir air dan kerangka dudukan

\subsection{Perancangan Sistem}

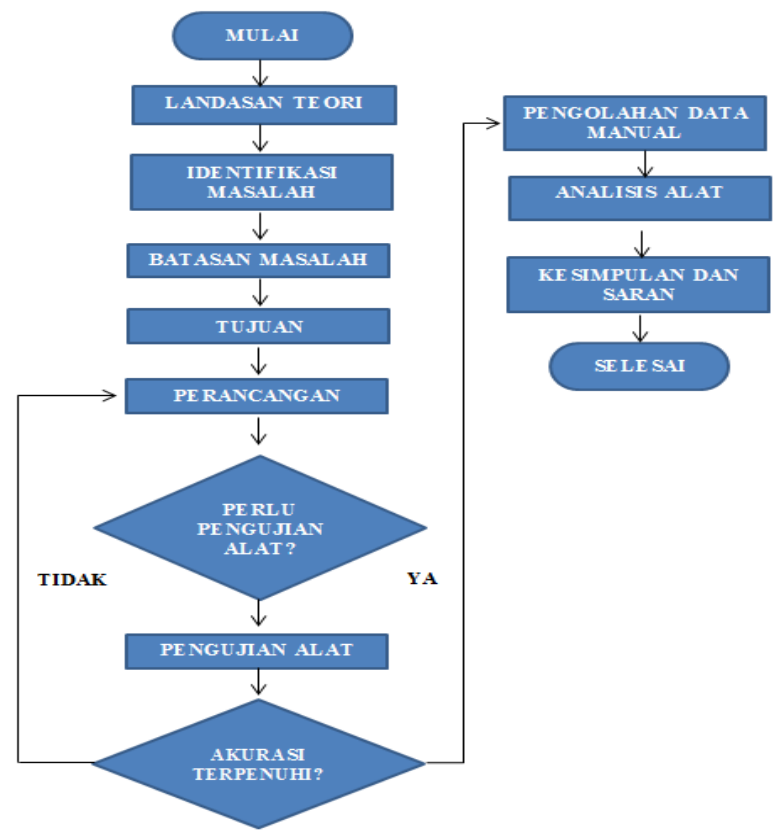

Gambar 1. Diagram alir perancangan

Dalam perancangan sistem, maka dilakukan seperti langkah-langkah pada gambar 1, dari mulai pengumpulan referensi pendukung penelitian hingga menyimpulkan hasil penelitian yang didapatkan.

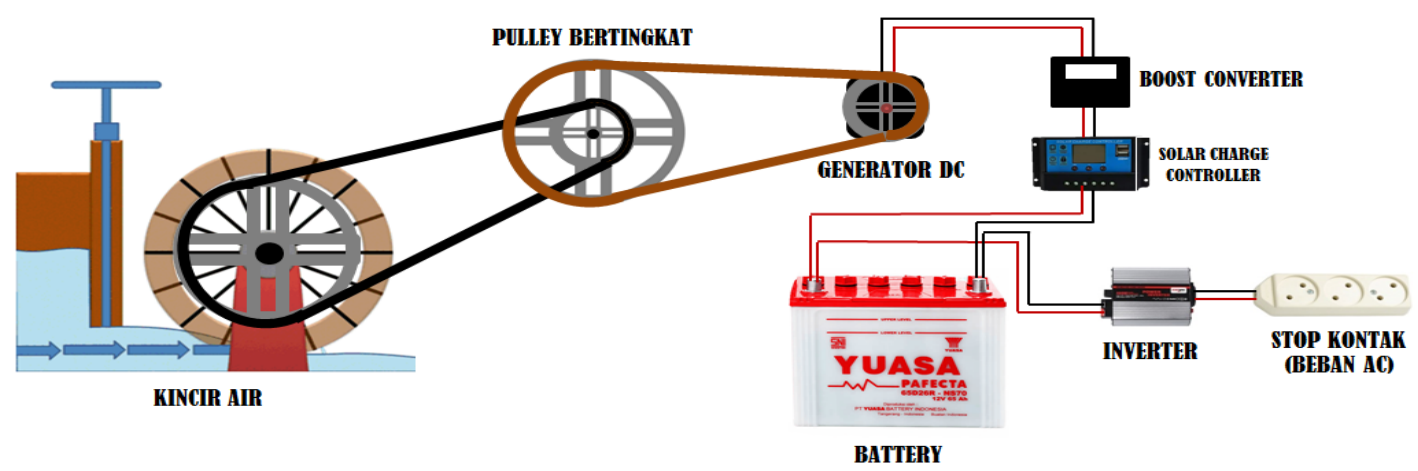

Gambar 2. Rangkaian sistem kincir air

Rangkaian sistem kincir air ini terdiri atas plat aeser 1,2 $\mathrm{mm}$ sebagai komponen utama pembuatan kincir, besi hollow $20 \mathrm{~mm}$ digunakan sebagai kerangka dan dudukan dari kincir, pulley 3 inc dan 13 inc yang dirangkai bertingkat agar mencapai rpm yang maksimal, besi poros $\varnothing 10 \mathrm{~mm}$ x $6 \mathrm{~m}$ sebagai poros kincir, generator DC $12 \mathrm{~V}-18 \mathrm{~V} ; 30 \mathrm{~W}$ sebagai komponen yang mengubah putaran kincir yang digerakan oleh aliran arus air, menjadi energi listrik yang akan mengisis baterai, baterai $12 \mathrm{~V}-32 \mathrm{Ah}$, inverter $300 \mathrm{~W}$, dan rangkaian pembebanan lampu. 
Dalam melakukan pengujian dilakukan analisis pengukuran debit menggunakan persamaan:

$Q=A . v$

keterangan:

$$
\begin{aligned}
& \mathrm{Q}=\text { Debit air, } \mathrm{m}^{3} / \mathrm{s} \\
& \mathrm{V}=\text { Kecepatan air, } \mathrm{m} / \mathrm{s} \\
& \mathrm{A}=\text { Luas penampang, } \mathrm{m}^{2}
\end{aligned}
$$

Kemudian menganalisis lama waktu pengisian baterai menggunakan persamaan watt hour dengan mengetahui daya yang dihasilkan menggunakan persamaan:

$P_{\text {out }}=V . I$

keterangan:

$$
\begin{aligned}
& \text { Pout = daya output (Watt) } \\
& \mathrm{I}=\text { arus listrik (Ampere) } \\
& \mathrm{V}=\text { tegangan listrik (Volt) }
\end{aligned}
$$

Untuk menghitung lama waktu pengisian menggunakan persamaan watt hour:

$$
\text { Lama pengisian }=\frac{\text { Daya Batre }}{\text { Daya Generator }}
$$

Pembangkit listrik tenaga hybrid pico hydro adalah suatu gabungan antara pembangkit listrik tenaga air dan tenaga surya. Aliran air pada sungai kecil atau selokan dapat dimanfaatkan sebagai pembangkit listrik pico hydro, dengan perancangan sebuah kincir air yang kemudian akan dihubungkan dengan pulley bertingkat dengan rasio $1: 4$ agar menghasilkan tenaga yang maksimal untuk menggerakkan generator listrik, dan juga ada penambahan komponen boost converter sebagai menaikan tegangan agar menghasilkan tegangan yang sesuai (Jasa, 2010).

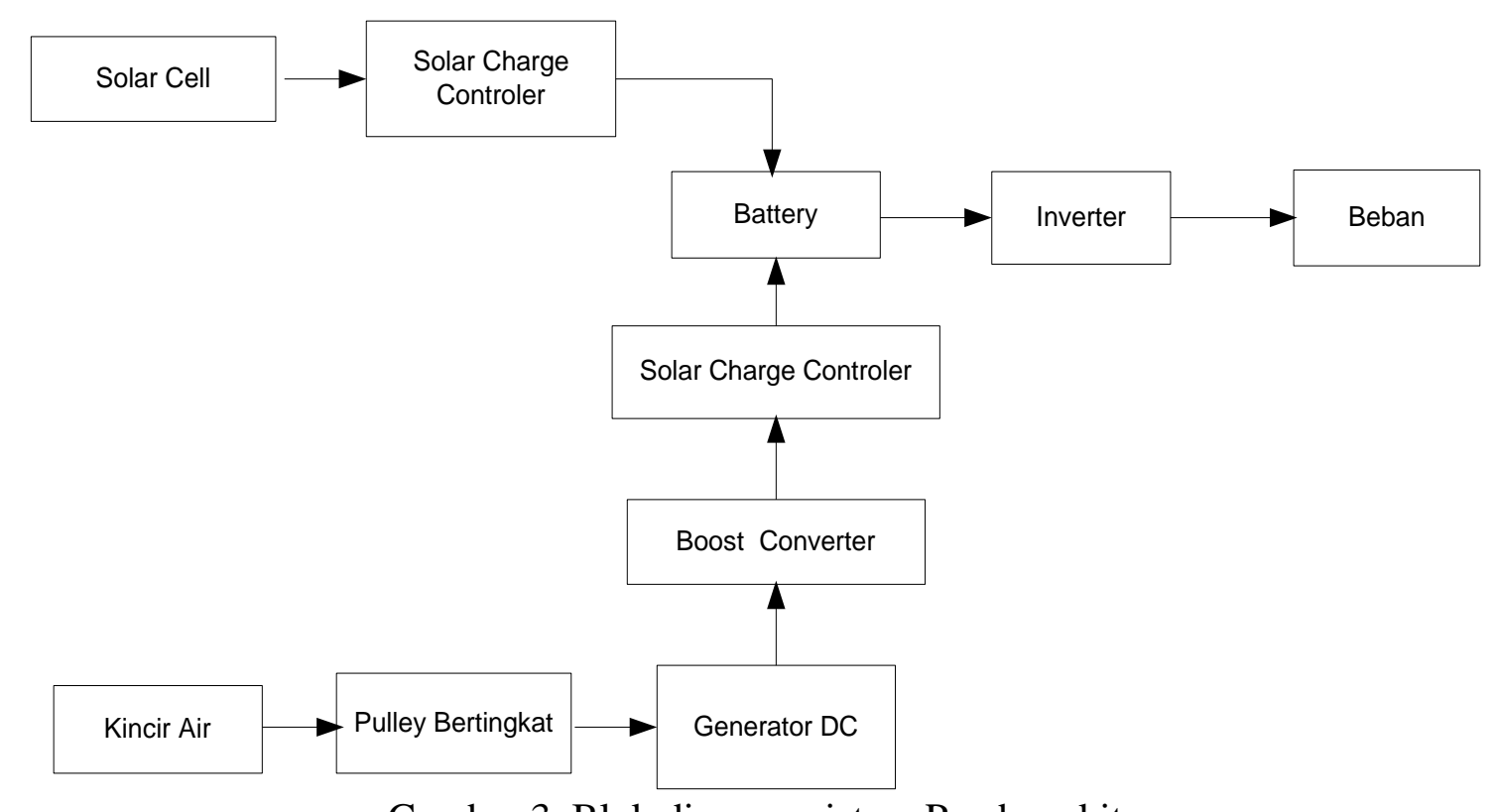

Gambar 3. Blok diagram sistem Pembangkit 


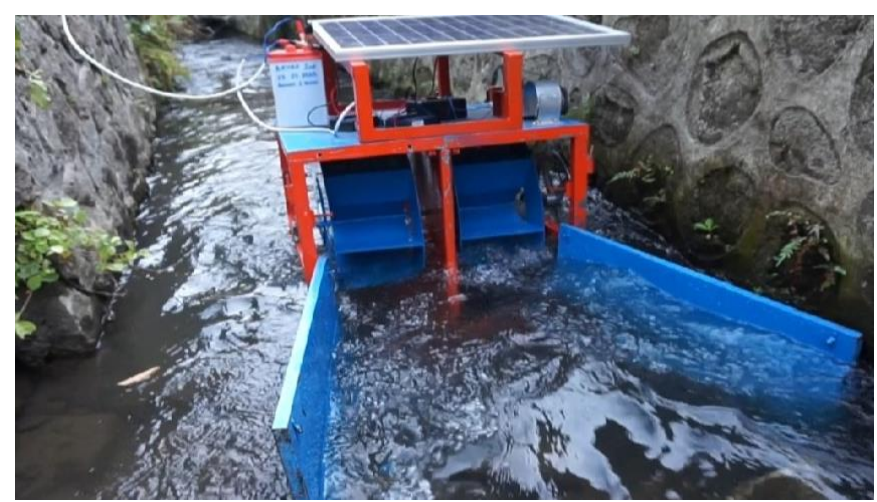

Gambar 4. Pembangkit Listrik Hybrid Pico Hydro

Berdasarkan pada pemanfaatan aliran irigasi, maka masyarakat Desa Wukirsari:

1. Dapat menambah wawasan yang luas tentang pemahaman dan penguasaan teknologi tepat guna, daya guna serta hasil guna sebagai sarana yang membantu meningkatkan perekonomian di Desa Wukirsari sehingga semakin menjamin keamanan dan kenyamanan dalam hidup bermasyarakat.

2. Ketersediaan aliran air dari irigasi dan sinar matahari yang cukup dengan pembangkit listrik tenaga Hybrid Pico Hydro, maka masyarakat khususnya dusun Wukirsari akan mendapat listrik penerangan jalan secara gratis.

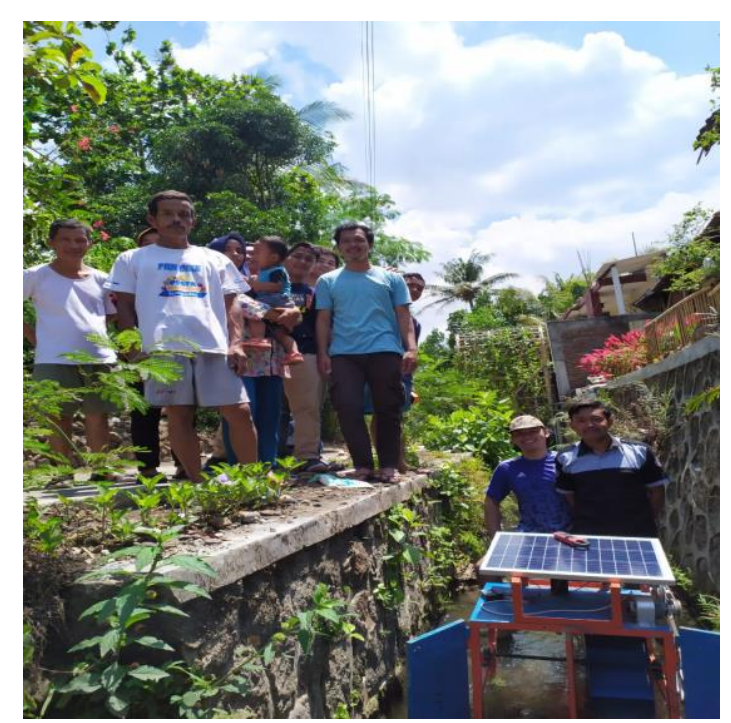

Gambar 5. Antusias warga masyarakat berpartisipasi dalam pemasangan Pembangkit Listrik Tenaga Hybrid Pico Hydro

\section{Hasil dan Pembahasan}

Untuk menguji sistem hybrid yang menggunakan kinerja single dan double kincir air dan didukung dengan rangkaian sistem solar panel untuk mempercepat pengisian baterai, sehingga dilakukan 2 jenis pengujian, yaitu pengujian tanpa beban dan pengujian berbeban.

Pengujian tanpa beban dilakukan dengan merangkai keseluruhan sistem baik kinerja single maupun double, namun belum diberikan pembebanan, dengan tujuan untuk mengetahui berapa besar tegangan dan arus yang dihasilkan dari rangkaian sistem sebelum diberikan beban. 
Tabel 1. Hasil pengujian tanpa beban ketinggian $37 \mathrm{~cm}$

\begin{tabular}{cccc}
\hline Percobaan & $\begin{array}{c}\text { Debit air } \\
\left(\mathrm{m}^{3} / \mathrm{s}\right)\end{array}$ & $\begin{array}{c}\text { Daya }(\mathrm{W}) \\
\text { Pada Single } \text { kincir }\end{array}$ & $\begin{array}{c}\text { Daya }(\mathrm{W}) \\
\text { Pada Double } \text { kincir }\end{array}$ \\
\hline 1 & 0,708 & 3,15 & 2,1 \\
2 & 0,708 & 3,23 & 2,14 \\
3 & 0,708 & 3,21 & 2,12 \\
4 & 0,708 & 3,32 & 2,05 \\
5 & 0,708 & 3,1 & 2,18 \\
\hline
\end{tabular}

Tabel 2. Hasil berbeban ketinggian $37 \mathrm{~cm}$

\begin{tabular}{cccc}
\hline $\begin{array}{c}\text { Beban } \\
(\mathrm{W})\end{array}$ & $\begin{array}{c}\text { Debit air } \\
\left(\mathrm{m}^{3} / \mathrm{s}\right)\end{array}$ & $\begin{array}{c}\text { Daya }(\mathrm{W}) \\
\text { Pada Single } \text { kincir }\end{array}$ & $\begin{array}{c}\text { Daya }(\mathrm{W}) \\
\text { Pada Double } \text { kincir }\end{array}$ \\
\hline 5 & 0,708 & 0 & 0 \\
10 & 0,708 & 2,25 & 1,84 \\
20 & 0,708 & 2,07 & 1,81 \\
25 & 0,708 & 2,95 & 2,8 \\
30 & 0,708 & 2,29 & 2,28 \\
35 & 0,708 & 2,56 & 2,56 \\
40 & 0,708 & 2,21 & 2,05 \\
45 & 0,708 & 2,33 & 3,5 \\
50 & 0,708 & 4,08 & 3,84 \\
60 & 0,708 & 1,77 & 1,77 \\
\hline
\end{tabular}

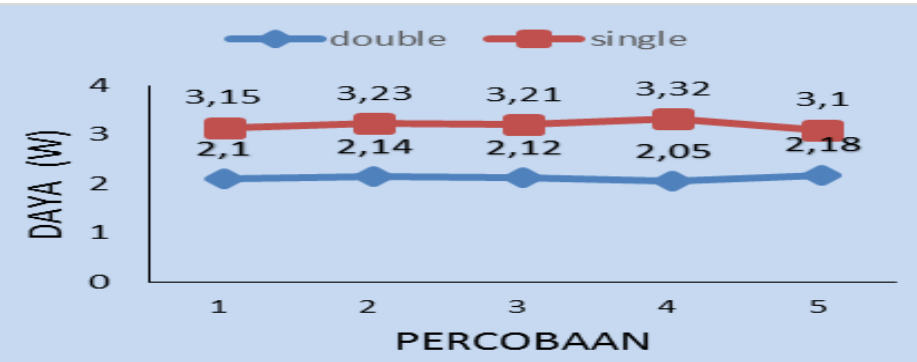

Gambar 6. Grafik perbandingan daya pengujian tanpa beban ketinggian $37 \mathrm{~cm}$

Grafik pengujian tanpa beban pada ketinggian air $37 \mathrm{~cm}$ menunjukan bahwa kinerja single kincir menghasilkan besaran daya listrik yang lebih besar dibandingkan dengan kinerja double kincir karena tekanan airnya lebih besar.. Namun daya yang dihasilkan tidak tetap dan cenderung berubah - ubah setiap waktunya. Kinerja single mendapatkan nilai daya sebesar 3,15W, 3,23W, $3,21 \mathrm{~W}, 3,32 \mathrm{~W}$, dan $3,1 \mathrm{~W}$. Sedangkan double kincir mendapatkan nilai daya sebesar 2,1W, 2,14W, $2,12 \mathrm{~W}, 2,05 \mathrm{~W}$, dan $2,18 \mathrm{~W}$.

Tabel 3. Hasil pengujian single kincir tanpa beban ketinggian air $37 \mathrm{~cm}$

\begin{tabular}{ccc}
\hline Percobaan & Rpm generator & Daya $(\mathrm{W})$ \\
\hline 1 & 448 & 3.15 \\
2 & 446 & 3.23 \\
3 & 422 & 3.21 \\
4 & 437 & 3.32 \\
5 & 441 & 3.1 \\
\hline
\end{tabular}




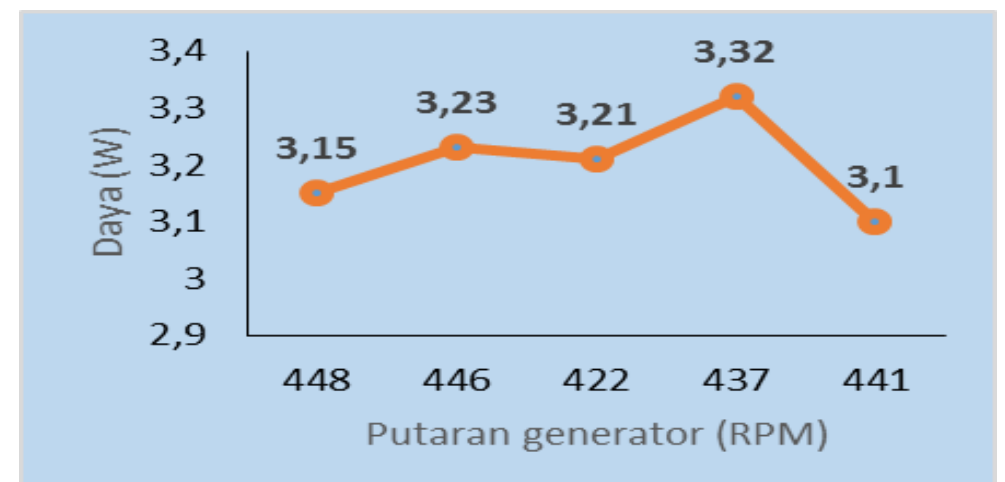

Gambar 7. Grafik pengujian single kincir tanpa beban ketinggian $37 \mathrm{~cm}$

Gambar grafik di atas menunjukan perbandingan rpm generator terhadap daya yang dihasilkan oleh sistem single kincir air pada ketinggian air $37 \mathrm{~cm}$, dari grafik dapat dilihat bahwa rpm yag didapat generator berubah ubah karena aliran arus air yang tidak tetap setiap waktunya, sehingga besar kecilnya rpm yang didapat generator tidak mempengaruhi daya yang dihasilkan. Pada grafik menunjukan bahwa nilai daya tertinggi yaitu pada rpm 437, sedangkan terendah pada rpm 441 .

Tabel 4. Hasil pengujian double kincir tanpa beban ketinggian air $37 \mathrm{~cm}$

\begin{tabular}{ccc}
\hline Percobaan & Rpm generator & Daya $(\mathrm{W})$ \\
\hline 1 & 392 & 2.1 \\
2 & 394 & 2.14 \\
3 & 395 & 2.12 \\
4 & 392 & 2.05 \\
5 & 393 & 2.18 \\
\hline
\end{tabular}

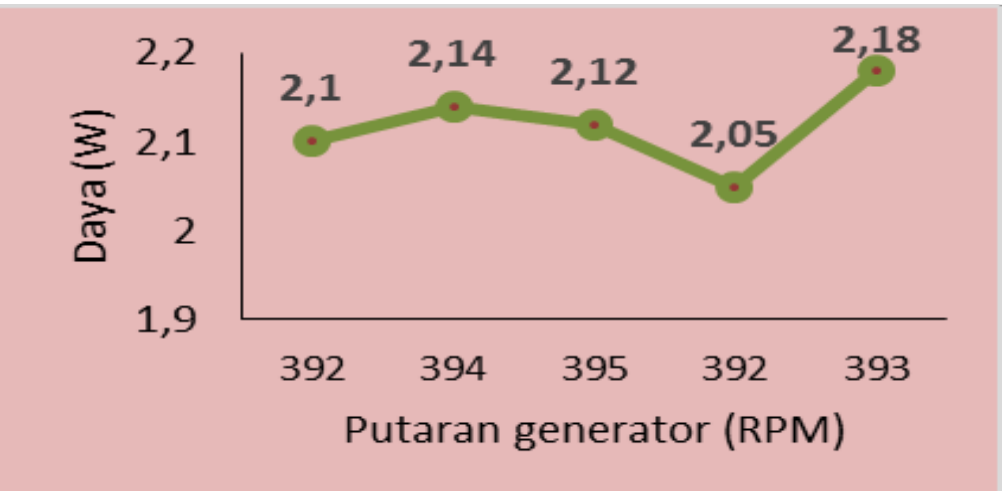

Gambar 8. Grafik pengujian double kincir tanpa beban ketinggian $37 \mathrm{~cm}$

Pada pengujian berbeban variabel yang digunakan yaitu berupa rangkaian pembebanan yang terdiri dari beberapa lampu pijar dari kapasitas $5 \mathrm{~W}$ sampai $60 \mathrm{~W}$. Pada gambar 8 menunjukan perbandingan nilai daya yang tidak tetap dan selalu berubah-ubah dan cenderung naik turun antara kedua kinerja kincir tersebut. Pada kinerja single kincir mendapatkan nilai daya tertinggi pada beban $45 \mathrm{~W}$ yaitu sebesar 3,87 W, sedangkan pada kinerja double kincir mendapatkan nilai daya tertinggi pada beban $50 \mathrm{~W}$ yaitu sebesar $3,84 \mathrm{~W}$, dan nilai beban terendah kedua kinerja tersebut pada beban $5 \mathrm{~W}$ yaitu $0 \mathrm{~W}$. Kinerja single kincir memiliki nilai rata-rata daya lebih besar dibandingkan dengan double kincir. 


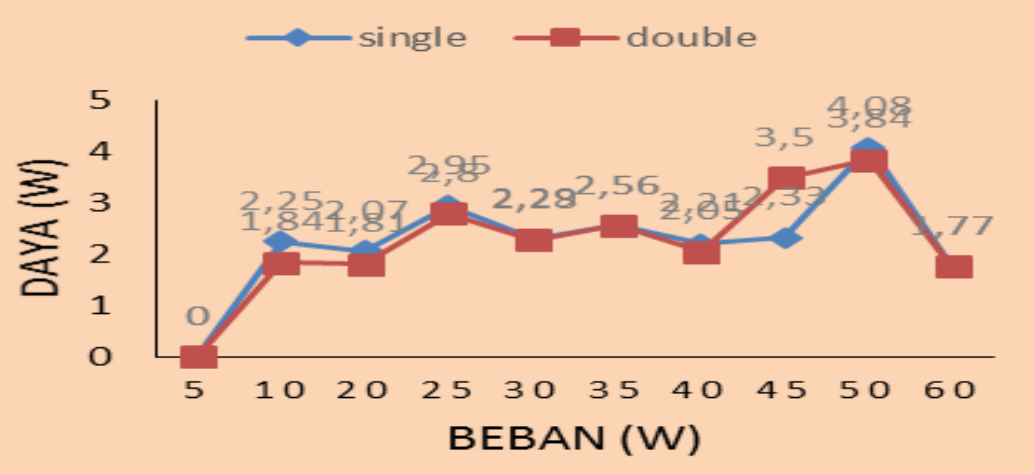

Gambar 9. Grafik perbandingan daya pengujian berbeban ketinggian air $37 \mathrm{~cm}$

Pada pengujian berbeban variabel yang digunakan yaitu berupa rangkaian pembebanan yang terdiri dari beberapa lampu pijar dari kapasitas $5 \mathrm{~W}$ sampai $60 \mathrm{~W}$, hanya sampai $60 \mathrm{~W}$ karena sistem kinerja kincir air tersebut memiliki batas drop tegangan baterai pada beban $60 \mathrm{~W}$. Pada grafik diatas menunjukan perbandingan nilai daya antara kinerja single dan double kincir air pada ketinggian air $37 \mathrm{~cm}$ atau pada saat pintu air ditutup. Hasil tersebut menunjukan nilai daya yang tidak tetap dan selalu berubah-ubah dan cenderung naik turun antara kedua kinerja kincir tersebut. Pada kinerja single kincir mendapatkan nilai daya tertinggi pada beban $50 \mathrm{~W}$ yaitu sebesar 4,08 W, Atau mendapatkan nilai daya tertinggi yang sama.

Tabel 5. Pengujian solar panel

\begin{tabular}{ccccc}
\hline No & Jam & Tegangan $(\mathrm{V})$ & Arus $(\mathrm{I})$ & Daya $(\mathrm{Wh})$ \\
\hline 1 & 10.00 & 13,2 & 1,1 & 14,52 \\
2 & 10.30 & 13,2 & 1,7 & 22,44 \\
3 & 11.00 & 13,3 & 2,5 & 33,25 \\
4 & 11.30 & 13,3 & 2,4 & 31,92 \\
5 & 12.00 & 13,4 & 2,4 & 32,16 \\
6 & 12.30 & 13,3 & 1,8 & 23,94 \\
7 & 13.00 & 13,2 & 1,03 & 13,59 \\
8 & 13.30 & 13,0 & 0,96 & 12,48 \\
9 & 14.00 & 12,9 & 0,64 & 8,25 \\
10 & 14.30 & 12,7 & 0,62 & 7,87 \\
\hline
\end{tabular}

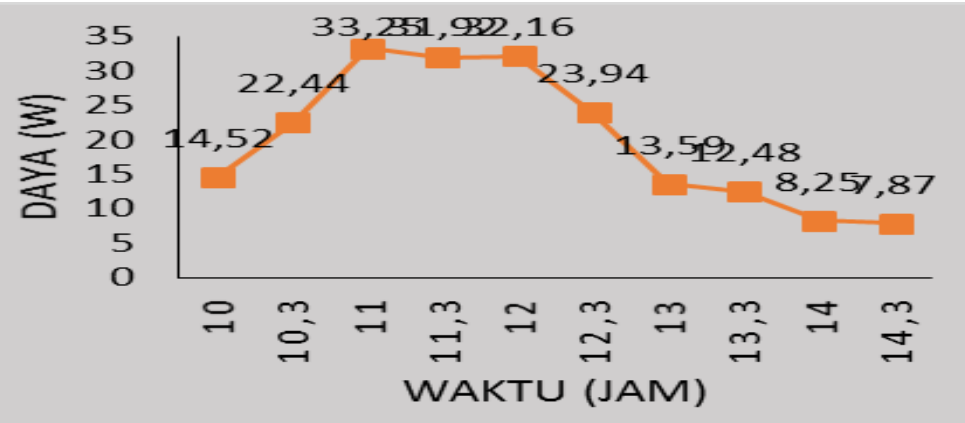

Gambar 10. Grafik perbandingan daya pengujian tanpa beban ketinggian $37 \mathrm{~cm}$

Pada grafik diatas menunjukan bahwa tingkat waktu sangat mempengaruhi daya yang dihasilkan, pada jam 11.00 wib mendapatkan nilai daya yang paling tinggi yaitu 33,25 W, sedangkan pada jam 14.30 wib mendapatkan nilai daya sebesar 7,87 W. sehingga dapat disimpulkan bahwa semakin terik intensitas panas matahari semakin tingi pula daya yang dihasilkan. Dan pada 
penelitian ini intensitas panas matahari tertinggi pada jam 11.00 WIB dan terendah pada jam 14.30 WIB.

\section{Kesimpulan}

Kincir air kinerja single pada ketinggian $37 \mathrm{~cm}$ memiliki rpm sebesar $25 \mathrm{rpm}$. Sedangkan pada double kincir pada ketinggian $37 \mathrm{~cm}$ memiliki rpm sebesar $23 \mathrm{rpm}$. Kinerja kincir air berubah-ubah karena aliran arus air yang tidak tetap setiap waktunya.

Nilai daya yang dihasilkan dari rangkaian sistem baik kinerja single maupun double cenderung berubah-ubah karena tegangan dan arusnya yang tidak stabil. Pengujian tanpa beban pada kinerja single kincir di ketinggian air $37 \mathrm{~cm}$ mendapatkan nilat rata-rata daya sebesar 3,2 W. Sedangkan pada kinerja double kincir pada ketinggian $37 \mathrm{~cm}$ mendapatkan 2,11 W. Sedangkan pada percobaan pembebanan kinerja single dan double mendapatkan nilai daya tertinggi sebesar 4,08W dan 3,87W.

Tegangan dan arus generator yang dihasilkan menyesuaikan dari kinerja kincir air tersebut. Arus yang tidak stabil akan mempengaruhi tegangan dan arus yang dibangkitkan generator. Pada kinerja single menghasilkan tegangan dan arus sebesar $6,72 \mathrm{~V}$ dan $0,46 \mathrm{~A}$, sedangkan kinerja double sebesar 5,36 V dan 0,38 A.

\section{Saran}

Dilakukan penjadwalan pada masyarakat untuk pemeliharaan yang kontinyu pada pembagkit listrik tenaga hybrid solar cell dan pico hydro ini terutama pada bateray yang harus ada perawatan khusus, sehingga menambah tercapainya penyaluran energi alternatif yang menguntungkan dan juga akan menambah keawetan alat tersebut. Untuk desa-desa yang berpotensi alat ini bisa dimabil sebagai contoh sebagai pembangkit listrik alternatif untuk penerangan jalan.

\section{Daftar Pustaka}

Alipan, N., \& Yuniarti, N. (2018). Pengembangan Pembangkit Listrik Tenaga Pico-Hydro. Edukasi Elektro, 2(2), 59-70.

Barat, D. I. S. (n.d.). Rancang Bangun Kincir Air Sistem Knock Down. 88-96.

Budiartawan, K., Suryawan, A. A. A., \& Suarda, M. (2017). Pengaruh Variasi Sudut Sudu Segitiga Terhadap Performansi Kincir Air Piko Hidro. Jurnal Ilmiah Teknik Desain Mekanika, 6(3), 294-298. https://ojs.unud.ac.id/index.php/mekanika/article/view/37480

Jasa, L. (2010). Mengatasi Krisis Energi dengan Memanfaatkan Aliran Pangkung sebagai Sumber Pembangkit Listrik Alternatif. Teknologi Elektro, 9(2), 182-190.

Junaidi, A., Rinaldi, \& Hendri, A. (2014). Model Fisik Kincir Air Sebagai Pembangkit Listrik. Jom FTEKNIK, 1(2), 1-9. https://media.neliti.com/media/publications/206233-model-fisikkincir-air-sebagai-pembangki.pdf

Mesin, J. T., Teknik, F., \& Riau, U. (2017). Pengujian Prestasi Kincir Air Tipe Overshot Di Irigasi Kampus. 4(1), 2-6.

Wibawa, U., Sc, M., Santoso, H., Dharmayana, I. G. A., \& Haryono, J. M. T. (n.d.). PERANCANGAN KINCIR AIR PEMBANGKIT LISTRIK TENAGA MIKROHIDRO ( PLTMH ) DESA BENDOSARI KECAMATAN PUJON KABUPATEN MALANG Jurusan Teknik Elektro Fakultas Teknik Universitas Brawijaya Kebutuhan akan energi listrik pada beberapa tahun terakhir di Indonesia sema. 45-58. 